\title{
Use of tree species by White-throated treerunner (Pygarrhichas albogularis King) in a secondary native forest of southern Chile
}

\author{
Alberto Gantz', Miguel Yañez², José I. Orellana ${ }^{1,3}$, Soraya Sade' \& Carlos E. Valdivia'
}

1. Laboratorio de Ecología, Departamento de Ciencias Biológicas y Biodiversidad, Universidad de Los Lagos, Casilla 933, Osorno, Chile. (agantz@ulagos.cl)
2. Departamento de Estadística, Facultad de Ciencias, Universidad del Bio Bio, Concepción, Chile. (myanez@ubiobio.cl)
3. Centro de Estudios en Biodiversidad, Magallanes 1979, Osorno, Chile. (centrobioch@gmail.com)

\begin{abstract}
In forest ecosystems, numerous species of insectivorous birds use certain tree species as feeding and nesting substrates. Between 2009 and 2010, the use of different floristic components as feeding substrate by the Pygarrhichas albogularis King, 1831 was evaluated in a southern Chilean secondary native forest. From a total of 13 trees and bush species, six tree species were used by P. albogularis as a feeding substrate. Tree use was limited to intermediate heights $(11-20 \mathrm{~m})$ and, mainly, to the trunk (40\% of observations) and secondary branches (26\%). Pygarrhichas albogularis showed a disproportionated use of $N$. dombeyi and an important use of trees with a greater age structure (DBH 81-100 cm). Nothofagus dombeyi presented a significantly greater tree bark crevice depth than E. cordifolia. In turn, covariance between crevice depth and invertebrate supply in tree bark was positive and significant. We consider bark depth and invertebrate supply to be the proximate causes explaining $P$. albogularis disproportionated use of Nothofagus dombeyi.
\end{abstract}

KEYWORDS. Temperate forest, Chile, White-throated Treerunner, floristic use.

RESUMEN. Uso de especies de árboles por el Comesebo Grande (Pygarrhichas albogularis King) en un bosque nativo secundario del sur de Chile. En ecosistemas boscosos, numerosas especies de aves insectívoras usan ciertas especies de árboles como sustrato de alimentación y de nidificación. Evaluamos el uso de Pygarrhichas albogularis King, 1831 por componentes florísticos utilizados como sustrato de alimentación en un bosque nativo en el sur de Chile entre el 2009 y 2010. De 13 especies de árboles y arbustos $P$. albogularis utilizó seis especies de árboles como sustrato de alimentación. El uso de los árboles se limitó a alturas intermedias (11-20 m) y principalmente utilizó el tronco (40\% observaciones) y las ramas secundarias (26\%) de los árboles como sustrato de alimentación. Pygarrhichas albogularis mostró un uso desproporcionado por Nothofagus dombeyi y un uso importante por árboles con la mayor estructura etárea (DAP 81-100 cm). Por su parte, $N$. dombeyi presentó una profundidad de las grietas de la corteza significativamente mayor que E. cordifolia. A su vez, la profundidad de las grietas covarió positiva y significativamente con la oferta de invertebrados en la corteza de los árboles. Consideramos la profundidad de la corteza y la oferta de invertebrados como las causas próximas que podrían explicar el uso desproporcionado de $P$. albogularis por Nothofagus dombeyi.

PALABRAS-CLAVE. Bosque templado, Chile, Comesebo grande, uso florístico.

Generally, species diversity has been associated with heterogeneity of habitat structural variables (RoBINSON \& Holmes, 1984; Freemark \& Merriam, 1986; Laiolo, 2002). Nevertheless, the importance attributed to vegetation structure as the proximate cause of species richness, could underestimate the significance of forest floristic components as a determinant factor in bird presence and abundance (Estades, 1997; GabBe et al., 2002). For example, many species of insectivorous birds are habitat specialists that show a non-random use of particular tree species (HoLmes \& Robinson, 1981; Rogers, 1985; GabBe et al., 2002; LeE \& Rotenberry, 2005; BöHM \& KaLKo, 2009; WoOD et al., 2012).

The White-throated Treerunner (Pygarrhichas albogularis) is widely distributed throughout Chile, and it is present in Mediterranean, moist-temperate and subantartic bioclimatic zones (ARRAYA \& MILLIE, 1986; REID et al., 2002; MARTíNEZ \& GoNZÁLEZ, 2004). It is an endemic insectivorous species and an annual resident of the South American temperate forests (REID et al., 2002; BIRDLIFE, 2009). It feeds mainly on the trunks and branches of live trees (IPPI \& Trejo, 2003; Díaz et al., 2005), occupying secondary cavities for nesting (ReID et al., 2002). Feeding technique consists in lifting the tree bark in search of invertebrates and, occasionally, perforating the bark (IPPI \& TREJo, 2003). Although some references have suggest that P. albogularis use old trees for feeding and nest building (DíAz et al., 2005; WiLSON et al., 2005), the underlying mechanism that influence the use of tree species by the P. albogularis as feeding substrates in secondary forest, have not been explored.

The present study aims to: 1) Determine whether $P$. albogularis shows a preference use for floristic elements in a secondary native forest; 2) Assess the factors that justify an eventual use of the floristic resource and 3) Outline the importance of these floristic elements in P. albogularis conservation strategies.

\section{MATERIAL AND METHODS}

Study Area. The study was carried out in a 20 ha secondary native forest, located in the intermediate depression of Osorno province ( $40^{\circ} 54^{\prime} 38^{\prime \prime} \mathrm{S} ; 72^{\circ} 41^{\prime} 57^{\prime}$ 'W), Los Lagos Region, southern Chile. The vegetation is typical of the secondary temperate rain forests, classified as the inland temperate laurifolious forest strata of Nothofagus dombeyi (Mirb.) Oerst. and Eucryphia cordifolia Cav., of which only $54.8 \%$ (i.e., $5,589 \mathrm{~km}^{2}$ ) of the original surface 
area remains (see LuEberT \& PLISCOFF, 2006 for details). The emergent Nothofagus dombeyi and Eucryphia cordifolia trees have trunk diameters over $80 \mathrm{~cm}$ and a height of $35 \mathrm{~m}$. The sub-canopy is represented by trees intolerant to shade, such as Gevuina avellana, Laurelia sempervirens, Luma apiculata, Amomyrtus meli, and Rhaphithamnus spinosus (see Fig. 1 for the vertical profile of the studied forest). The shrub layer harbored individuals of Chusquea quila. The climate zone is temperate warm/rainy, with precipitations concentrated between May and August, reaching $1.300 \mathrm{~mm}$ annually, with mean annual temperature between 10-12 ${ }^{\circ} \mathrm{C}$ (Subiabre \& Rojas, 1994).

Use of floristic elements. During spring and summer 2009 and 2010, birds were detected visually in two lineal transects $150 \mathrm{~m}$ and $180 \mathrm{~m}$ length (length limited by forest edge), chosen at random from a total of 6 transects established a priori, spaced at $200 \mathrm{~m}$ intervals one from the other. Each transect was walked for 30 minutes between 07:00 and 10:00 h., on days without precipitations or strong winds. Once the bird was located it was followed only for 3-4 seconds and, its activity (feeding, resting, singing and preening) and precise position in the forest vegetation was described (O'Donnell \& DilKs, 1988; GABBE et al., 2002). The birds were observed by two observers with similar experience in identifying this bird and the vegetation it inhabits. In order to evaluate floristic element availability in both transects, 6-7 plots (number of plots determined by transect length) were established, $10 \mathrm{~m}$ in diameter (78.54 $\mathrm{m}^{2}$ each) (RADFORD \& BENNETT, 2004), at $20 \mathrm{~m}$ intervals, separated $5 \mathrm{~m}$ perpendicular to the transect. We used this technique because it is considered reliable and efficient for evaluate forest structure (RADFORD \& BENNETT, 2004). Habitat variables commonly considered to be important for forest birds were evaluated, such as: number and density of trees, bushes and shrubs, expressed as No/ha. (RoBINson \& Holmes, 1984; Morrison et al., 1992; DíAz et al., 2005; Seymour \& DeAn, 2009; Morrison \& Lindell, 2011).

Furthermore, number of dead standing trees was quantified, given that they may constitute a resource used by the birds (BLAKE \& KARR, 1987), as well as the DBH (Diameter at Breast Height) of the trees and bushes with DBH $>10 \mathrm{~cm}$. Height of the bird sighting in the tree was determined according to a qualitative scale: lower third, middle third and upper third of the trunk, while perch type was defined as: primary branches (bifurcated from the tree trunk), secondary branches (bifurcated from primary branches) and tertiary branches (bifurcated from the secondary branches).

Bark living invertebrates. The number of invertebrates can transform different species of trees into a more, or less, attractive resource for birds (Holmes \& Robinson, 1981). Thus, bark crevice depth was measured in three tree species: dead tree, Eucryphia cordifolia and Nothofagus dombeyi. Nevertheless, due to the reduced sample size during 2010, the evaluation was repeated in 2012 , in the same transects and plots as previous years. Thus, the covariance between bark crevice depth and relative number of bark living invertebrates (potential trophic resources) was examined. Other tree species were eliminated from the analysis, in view of the insignificant presence of fauna. Although invertebrate abundance and richness varies with tree height, for logistic reasons, sampling of tree bark depth was limited to 15 random measurements at breast height, with the aid of a metallic rule ( $1 \mathrm{~mm}$ precision). Any invertebrate detected at the same height in the tree bark, within 2 quadrants of $20 \mathrm{x}$

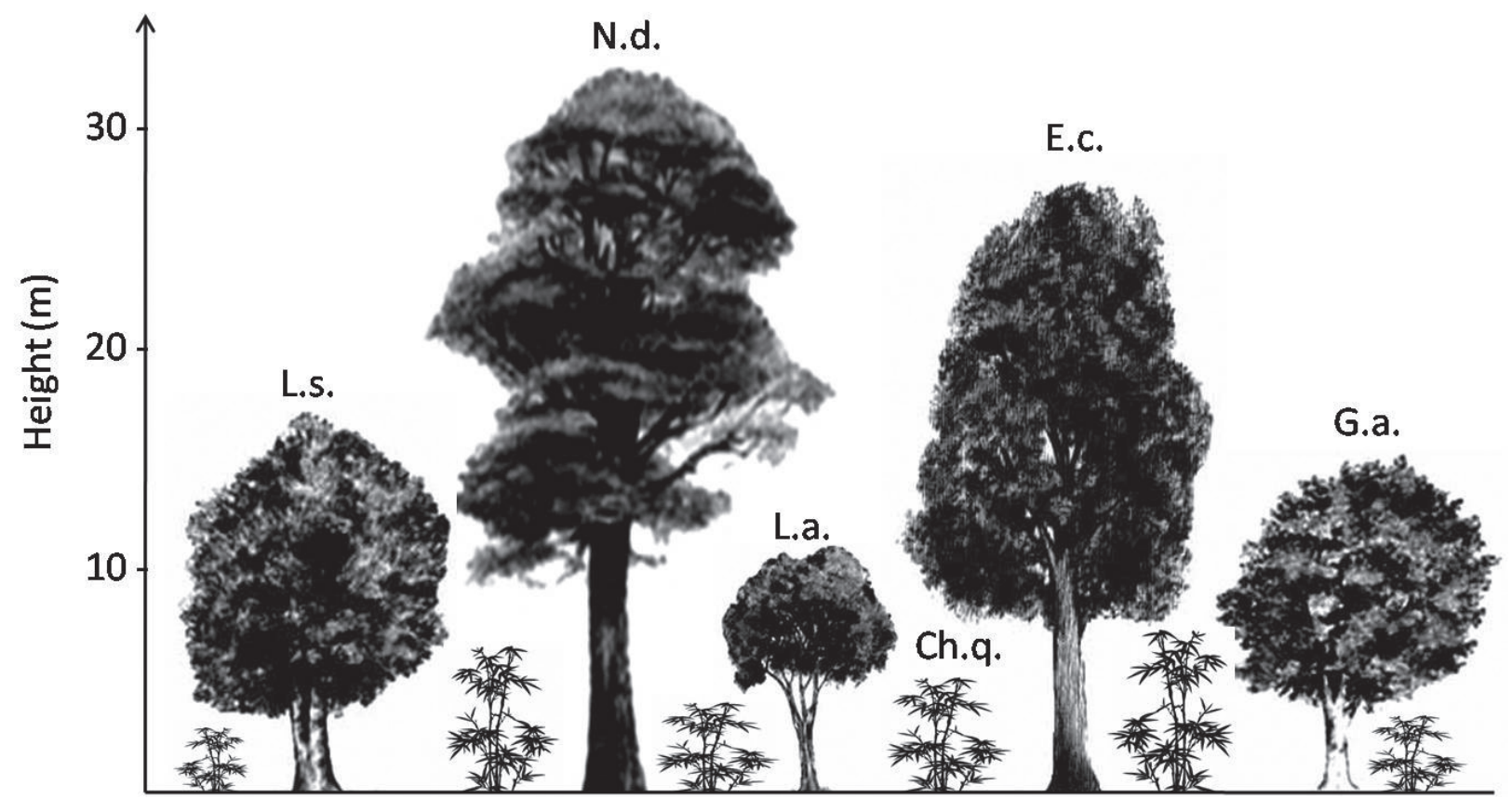

Fig. 1. Vertical profile of the laurifolious forest in the study area (Ch.q., Chusquea quila; E.c., Eucryphia cordifolia; G.a., Gevuina avellana; L.a., Luma apiculata; L.s., Laurelia sempervirens; $\mathrm{Nd}$, Nothofagus dombeyi). 
$20 \mathrm{~cm}\left(0.4 \mathrm{~m}^{2}\right.$ each one) were collected (JÄNTTI et al., 2001). Diameter of all trees used was over $25 \mathrm{~cm}$. The invertebrates were placed in paper bags and frozen $\left(-18^{\circ} \mathrm{C}\right)$ in the laboratory, for subsequent analysis. Invertebrate fauna at upper taxa level were classified, since, according to the study aims, supply of total invertebrates per tree sample is considered to be of greater interest than abundance of the particular taxa.

Statistical analysis. As a result of the non-linearity between tree bark depth and total prey in bark, the Spearman rank correlation was applied (SoKAL \& ROHLF, 1987; Siegel \& CASTellán, 1988) to describe the relationship between both variables. The Kruskal-Wallis test was applied to examine variation between DBH and bark depth between the different tree species. The Kruskal-Wallis test was also applied (prey density was considered as a response variable), together with multiple comparison tests of minimum differences (CONOVER, 1980), to test the hypothesis that tree trunk structure used by the birds (bark crevice depth) constitutes an explanatory variable for the relative number of invertebrates in the trunk bark.

Because we consider that there is a potential dependency among observation of birds in the forest we used only qualitative data for the analysis of tree species use by White-throated treerunner.

\section{RESULTS}

A total of 39 P. albogularis observations were made. All the birds observed (100\%) were feeding. Thus, we are certain that the trees used by $P$. albogularis constitute a feeding substrate. Of a total of 13 trees and bushes, $P$. albogularis used six species of trees and unidentified dead trees ( $46.1 \%$ of total trees recorded) as a feeding substrate. Other trees and bushes (i.e. Amomyrtus luma, Crinodendron hookerianum, Luma apiculata and Rhaphithamnus spinosus) were not used by the birds (Fig. 2). The dead trees, Nothofagus dombeyi, Nothofagus obliqua and Eucryphia cordifolia, were used most. In these trees, feeding height ranged between 11 and $20 \mathrm{~m}$. Similarly, feeding activity was concentrated in the middle third of the trunks $(40 \%$ of total observations), whereas the secondary branches were used to a lesser extent $(26 \%)$ as a feeding substrate.

Of the six types of trees used as a feeding substrate, $P$. albogularis showed a disproportionated use of Nothofagus dombeyi, three fold higher the frequency of use of Eucryphia cordifolia and the dead trees (Fig. 2 ). Additionally, our results showed that $P$. albogularis had a marked use for those trees with greater size ranges, centering their activity in trees with DBH of between 81 and $100 \mathrm{~cm}$ (Fig. 3).

Of the three tree types used by the birds, trunk diameter of $N$. dombeyi was significantly greater than that of Eucryphia cordifolia and the dead trees (Kruskal-Wallis ANOVA, $H=28.614 ; P=0.001)$. Similarly, $N$. dombeyi presented a significantly greater tree bark crevice depth than the other two types of trees (Kruskal-Wallis ANOVA, $H=37.413 ; P=0.001)$. Furthermore, it became evident that depth of tree bark crevices analyzed is a function dependent on tree trunk diameter. A highly significant

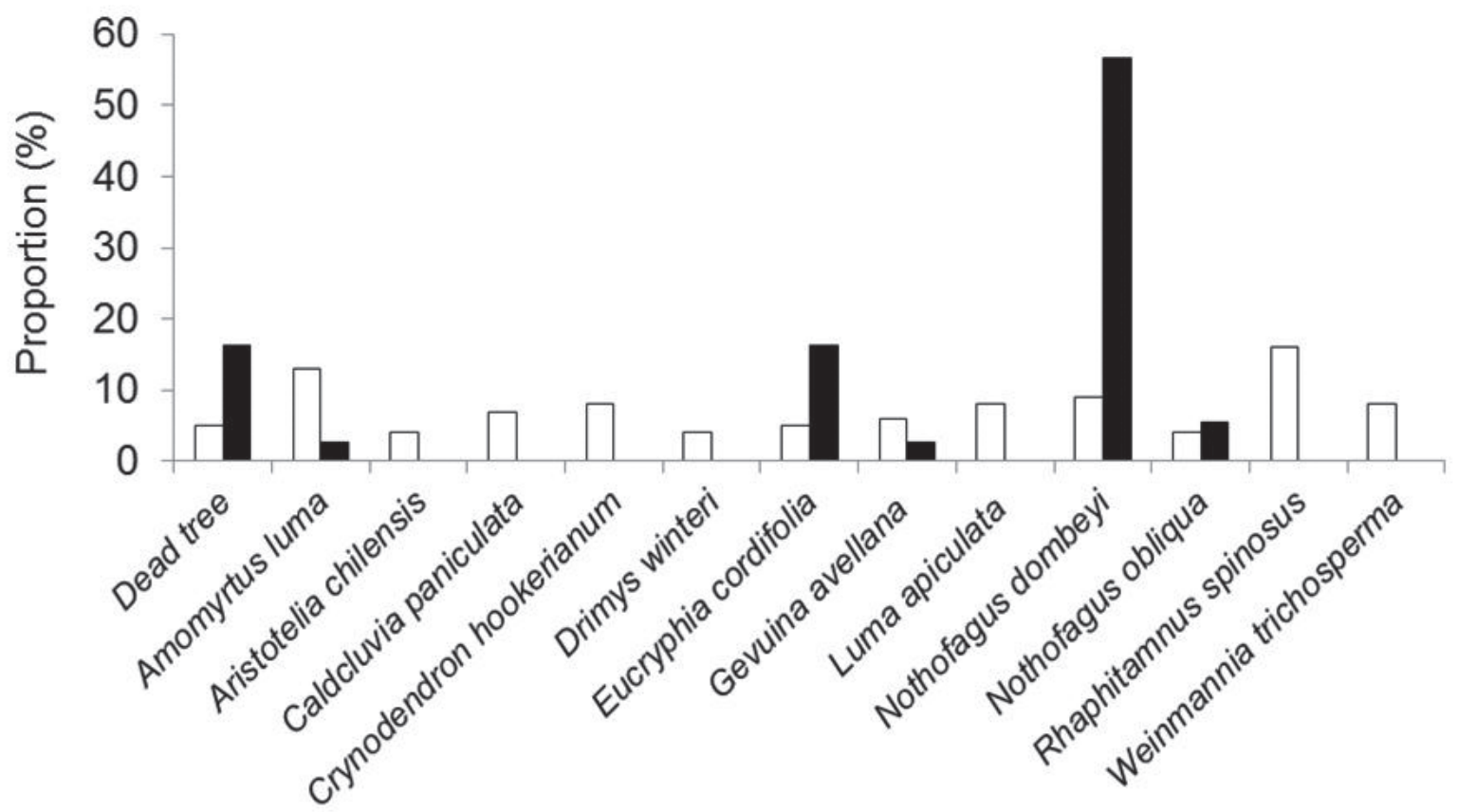

$\square$ Available trees $\quad$ Trees used by birds

Fig. 2. Proportion of Pygarrhichas albogularis King, 1831 individuals using different tree and shrub species available in a secondary native forest in southern Chile, during 2009-2010. 


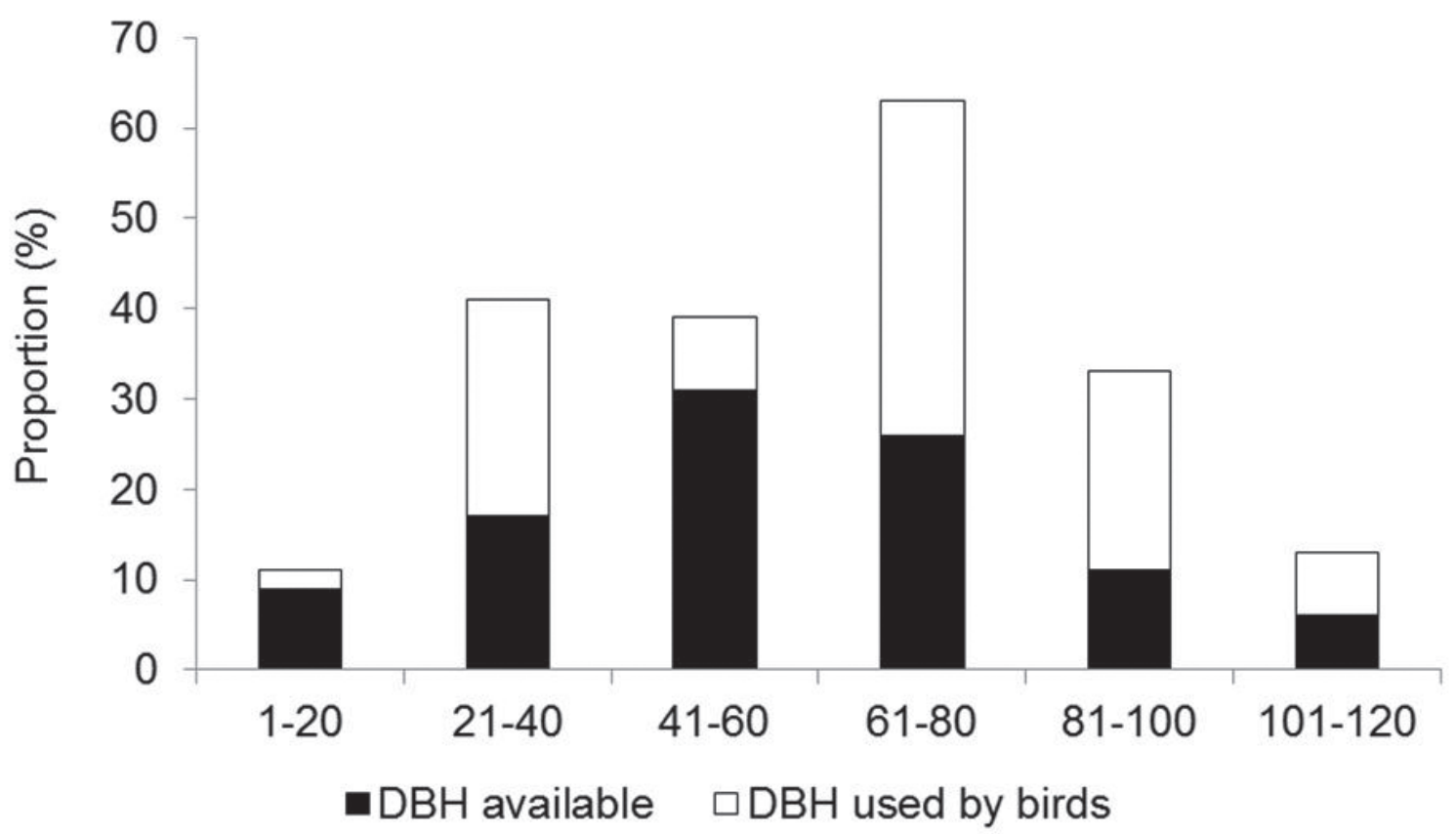

Fig. 3. Frequency distribution of age range (D.B.H.) of available trees and shrubs used by Pygarrhichas albogularis King, 1831, in a secondary native forest in southern Chile, during 2009-2010.

positive correlation exists between both variables $\left(\mathrm{r}_{\mathrm{s}}=\right.$ $0.899 ; P=0.001, N=60$ ). In turn, our results show that trunk crevice depth is a structural attribute of some species of trees, that has a positive and significant influence on the relative number of invertebrates present $\left(r_{s}=0.636\right.$; $P=0.001, N=60)$. In this regard, relative number of invertebrates in $N$. dombeyi trunk bark was significantly greater than in the other two tree species (Kruskal-Wallis ANOVA, $H=18.379 ; P=0.001)$. A subsequent multiple comparison test by ranges revealed that $E$. cordifolia presents a lower relative number of invertebrates and differs significantly with respect to $N$. dombeyi $(P=0.001)$. Nevertheless, presence of invertebrates does not differ between $E$. cordifolia and dead tree $(P=0.107)$. In all trees analyzed, a total of four invertebrate taxa, were found on the trunk bark. Adult insects and spiders were the most abundant invertebrates, together representing $78 \%$ of total invertebrates detected (Tab. I).

\section{DISCUSSION}

Pygarrhichas albogularis showed evident dependence on large trees in the southern Chilean forest and a disproportionated use for Nothofagus dombeyi as a feeding substrate. Bark structure of these tree trunks and the greater abundance of invertebrates accessible to birds, would constitute the proximate factors that explain the disproportionate use of Nothofagus dombeyi. Use of old trees is a common pattern in the bark feeding bird guild (Laiolo, 2002; Seymour \& Dean, 2009). Our results are in accordance with those of many authors with regard to the use and preferences of various insectivorous bird species for particular floristic elements (HoLmEs \& ROBINSON, 1981; Rogers, 1985; LeE \& Rotenberry, 2005; FinK et al., 2009; PiETREK \& BRANCH, 2011). These results enable us to suggest that the $P$. albogularis preferences for Nothofagus trees agree with that noted by LeE \& ROTEMBERRY (2005), who indicated that the bird-floristic composition association would be a function of variations in trophic resource availability offered by different tree species.

Nevertheless, old trees (particularly $N$. dombeyi) are more likely to generate natural holes (ToMASEvic \& ESTADES, 2004), offering greater nesting opportunities for birds. Thus, nesting cavity availability can constitute an additional potential variable inducing the preferential use of $P$. albogularis for some types of trees. Secondary nesting species, that depend on cavity availability in trees, such as this bird species, can be favored by the cavities

Tab. I. Number of invertebrates present in bark crevices of the three main tree species visited by birds in a secondary native forest in southern Chile, 2012 (\%, proportion of the total sample).

\begin{tabular}{lcccc}
\hline & $\begin{array}{c}\text { Dead Tree } \\
\mathrm{n}=6\end{array}$ & $\begin{array}{c}\text { Nothofagus dombeyi } \\
\mathrm{n}=27\end{array}$ & $\begin{array}{c}\text { Eucryphia cordifolia } \\
\mathrm{n}=29\end{array}$ & $\begin{array}{c}\text { TOTAL } \\
\mathrm{n}=77\end{array}$ \\
\hline Araneae & 1 & 37 & 5 & 43 \\
Insecta (adults) & 1 & 97 & 4 & 23.12 \\
Insecta (larvae) & 0 & 18 & 1 & 52 \\
Opiliones & 1 & 6 & 0 & 10 \\
Pseudoscorpionida & 3 & 10 & 2 & 7 \\
TOTAL & 6 & 168 & 12 & 15 \\
\hline
\end{tabular}


produced by Campephilus magellanicus. This latter species is a primary cavity nesting species in the temperate austral forests and a key cavity generating species, preferentially in Nothofagus trees (OJEDA et al., 2007). Thus, P. albogularis may be confined to using tree species preferred by primary excavators. More detailed studies are required to prove this hypothesis.

Although our sample size is reduced, the results of this study would have important implications for the conservation of this species. In this context, although $P$. albogularis is included in the Least Concern category (BIRDLIFE INTERNATIONAL, 2009), this does not ensure that populations are risk free (GASTON, 2010). Many researchers have suggested that, as a consequence of ecological specializations, insectivorous birds are particularly threatened by loss and degradation processes affecting habitat floristic components (JAMES \& WAMER, 1982; FreEMARK \& MERriam, 1986; BlaKe \& KarR, 1987; UEZU et al., 2005). As a consequence, $P$. albogularis restrictive use of floristic resources, together with frequent natural and anthropic disturbances affecting these forests, may increase the vulnerability of the populations that inhabit them. In effect, the frequent disturbances in the physiognomy and floristic composition of these forests, that have a negative effect on the $N$. dombeyi populations, can progressively reduce availability of those specific floristic resources use by $P$. albogularis. This can result in this bird species experiencing availability thresholds of these resources (TEllería \& DE SANTO, 1995) that can drastically reduce its survival probability in these forests. Finally, it remains to be established whether $P$. albogularis has preference patterns for floristic resources in other forests, with different sizes, structure and floristic composition, are similar to those found in the present study.

Acknowledgements. We want to thanks Mr. Guillermo Gedique who kindly allow us to work on his farm. The collaboration of Susan Angus in the translation of the manuscript, is also acknowledged. This study was posible by the financial support of the Dirección de Investigación de la Universidad de Los Lagos, Osorno, Chile (Proyect DI 0509).

\section{REFERENCES}

Arraya, B. \& Millie, G. 1986. Guía de campo de las aves de Chile. Santiago, Editorial Universitaria. 387p.

Birdlife International. 2009. The birdlife checklist of the birds of the world, with conservation status and taxonomic sources. Version 2. Available in $<$ http://www.birdlife.org/datazone/species/ downloads/>. Accessed on April 2010.

BlAKE, J. G. \& KARR, J. R. 1987. Breeding birds of isolated woodlots: area and habitat relationships. Ecology 68(6):1724-1734.

BöHM, S. M. \& Kalko, E. K. V. 2009. Pattern of resource use in an assemblage of birds in the canopy of a temperate alluvial forest. Journal of Ornithology 150:799-814.

Conover, W. J. 1980. Practical Nonparametric Statistics. 2ed. New York, John Wiley \& Sons. 493p.

DíAz, I. A.; Armesto, J. J.; Reid, Sh.; Sieving, K. E. \& Willson, M. F. 2005. Linking forest structure and composition: avian diversity in succesional forest of Chiloé Island, Chile. Biological Conservation 123:91-101.

ESTADES, C. F. 1997. Bird habitat relationships in a vegetational gradient in the Andes of central Chile. The Condor 99:719-727.
Fink, R. D.; Lindell, C. A.; Morrison, E. B.; Zahawi, R. A. \& Holl, K. D. 2009. Match size and tree species influence the number and duration of bird visits in forest restoration plots in southern Costa Rica. Restoration Ecology 17:479-486.

Freemark, K. E. \& MerRiam, H.G. 1986. Importance of area and habitat heterogeneity to bird assemblages in temperate forest fragments. Biological Conservation 36:115-141.

Gabbe, A. P.; Robinson, S. K. \& Brawn, J. D. 2002. Tree-species preferences of foraging insectivorous birds: Implications for flodplain forest restoration. Conservation Biology 16(2):462-470.

Gastón, K. J. 2010. Valuing common species. Science 327:154-155.

Holmes, R. T. \& Robinson, S. K. 1981. Tree species preferences of foraging insectivorous birds in a northern hardwood forest. Oecologia 48:31-35.

IPPI, S. \& TREJo, A. 2003. Dinámica y estructura de bandadas mixtas de aves en un bosque de Lenga (Nothofagus pumilo) del noroeste de la Patagonia Argentina. Ornitología Neotropical 14:353-362.

JAMES, F. C. \& WAMER, N. O. 1982. Relationshipsbetween temperate forest bird communities and vegetation structure. Ecology 63:159-171.

Jäntti, A.; Aho, T.; Hakkarainen, H.; Kuitunen, M. \& Suhonen, J. 2001. Prey depletion by foraging of the Eurasian treecreeper, Certhia familiaris, on tree-trunck arthropods. Oecologia 128:488-491.

LAIOLO, P. 2002. Effects of habitat structure, floral composition and diversity on a forest bird community in north-western Italy. Folia Zoologica 51(2): 121-128.

LEE, P. Y. \& RotenBERRY, J. T. 2005. Relationships between bird species and tree species assemblages in forested habitats of eastern North America. Journal of Biogeography 32:1139-1150.

Lueber, F. \& Pliscoff, P. 2006. Sinopsis bioclimática y vegetacional de Chile. Santiago, Chile, Editorial Universitaria. 316p.

MartíneZ, D. \& GonZÁlez, G. 2004. Las aves de Chile. Nueva Guía de campo. Santiago, Ediciones del Naturalista. 620p.

Morrison, E. B. \& Lindell, C. A. 2011. Active or pasive forest restoration? Assessing restoration alternatives with avian foraging behavior. Restoration Ecology 19:170-177.

Morrison, M. L.; Marcot, B. G. \& Mannan, R. W. 1992. WildlifeHabitat Relationships. Concepts and applications. Madison, The University of Wisconsin Press. 343p.

O’Donnell, C. F. J. \& Dilks, P. J. 1988. A method for quantifaying habitat use by forest birds. Wellington, Science and Research Directorate, Department of Conservation. 20p. (Science \& Research Series $\left.n^{\circ} 4\right)$.

Ojeda, V. S.; Suarez, M. L. \& Kitzberger, Th. 2007. Crown dieback events as key processes creating cavity habitat for magellanic woodpeckers. Austral Ecology 32:436-445.

Pietrek, A. G. \& BranCH, L. C. 2011. Native plantation as an important element for biodiversity in vanishing landscapes: A study of the near threatened araucaria tit spinetail (Leptasthenura setaria, Furnariidae). Austral Ecology 36:109-116.

RAdFord, J. Q. \& BennetT , A. F. 2004. Thresholds in landscape parameters: occurrence of the white-browed treecreeper Climacteris affinis in Victoria, Australia. Biological Conservation 117:375-391.

Reid, Sh.; Cornelius, C.; Barbosa, O.; Meynard, C. H.; Silva-García, C. \& MARQUET, P. A. 2002. Conservation of temperate forest birds in Chile: implications from the study of an isolated relict. Biodiversity and Conservation 11:1975-1990.

Robinson, S. K. \& Holmes, R. T. 1984. Effects of plant species and foliage structure on the foraging behavior of forest birds. The Auk 101:672-684

Rogers, CH. M. 1985. Foraging success and tree species use in the Least Flycatcher. The Auk 102:613-620.

Seymour, C. L. \& Dean, W. R. J. 2009. The influence of changes in habitat structure on the species composition of bird assemblages in the southern Kalahari. Austral Ecology 35(5):581-592.

Siegel, S. \& Castellán, N. J. 1988. Nonparametric statistics for the behavioral sciences. 2ed. Singapore, McGraw Hill. 399p.

SoKal, R. R. \& RoHLF, F. J. 1987. Introduction to Biostatistics. 2ed. New York, Dover Publications. 363p.

Subiabre, A. \& Rojas, C. 1994. Geografía física de la Región de Los Lagos. Valdivia, Ediciones Universidad Austral de Chile. 118p. 
Tellería, J. L. \& DE SANTo, T. 1995. Effects of forest fragmentation on a guild of wintering passerines: The role of habitat selection. Biological Conservation 71:61-67.

Tomasevic, J. A. \& Estades, C. F. 2004. Oferta de cavidades para aves de bosque en relación a parámetros dendrométricos en Hualo (Nothofagus glauca) y Coihue (Nothofagus dombeyi). Boletín Chileno de Ornitología 10:26-29.

Uezu, A.; MetzGer, J. P. \& Vielliard, J. M. E. 2005. Effects of structural and functional connectivity and patch size on the abundance of seven Atlantic forest bird species. Biological Conservation 123:507-519.
Willson, M. F.; Sieving, K. E. \& De Santo, T. L. 2005. Aves del bosque de Chiloé: diversidad, amenazas y estrategias de conservación. In: Smith-Ramirez, C.; Armesto J. J. \& Valdovinos, C. eds. Historia, biodiversidad y ecología de los bosques costeros de Chile. Santiago, Editorial Universitaria, p. 468-476

Wood, E. M.; Pidgeon, A. M.; Liu, F. \& Mladenoff, D. J. 2012. Birds see the trees inside the forest: The potential impact of changes in forest composition on songbirds during spring migration. Forest Ecology and Management 280:176-186. 